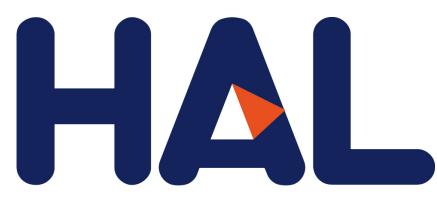

archives-ouvertes

\title{
Genetic structuring in a relictual population of screaming hairy armadillo (Chaetophractus vellerosus) in Argentina revealed by a set of novel microsatellite loci
}

Maximiliano Nardelli, Ezequiel Ibáñez, Dara Dobler, Fabienne Justy, Frédéric Delsuc, Agustín Abba, Marcelo Cassini, Juan Ignacio Túnez

\section{To cite this version:}

Maximiliano Nardelli, Ezequiel Ibáñez, Dara Dobler, Fabienne Justy, Frédéric Delsuc, et al.. Genetic structuring in a relictual population of screaming hairy armadillo (Chaetophractus vellerosus) in Argentina revealed by a set of novel microsatellite loci. Genetica, Springer Verlag, 2016, 144 (4), pp.469-476. 10.1007/s10709-016-9915-0 . hal-01879337

\section{HAL Id: hal-01879337 \\ https://hal.archives-ouvertes.fr/hal-01879337}

Submitted on 16 Nov 2018

HAL is a multi-disciplinary open access archive for the deposit and dissemination of scientific research documents, whether they are published or not. The documents may come from teaching and research institutions in France or abroad, or from public or private research centers.
L'archive ouverte pluridisciplinaire HAL, est destinée au dépôt et à la diffusion de documents scientifiques de niveau recherche, publiés ou non, émanant des établissements d'enseignement et de recherche français ou étrangers, des laboratoires publics ou privés. 


\section{Genetica}

\section{Genetic structuring in a relictual population of screaming hairy armadillo (Chaetophractus vellerosus) in Argentina revealed by a set of novel microsatellite loci \\ --Manuscript Draft--}

Manuscript Number:

Full Title:

Article Type:

Keywords:

Corresponding Author:
GENE-D-16-00071R2

Genetic structuring in a relictual population of screaming hairy armadillo

(Chaetophractus vellerosus) in Argentina revealed by a set of novel microsatellite loci

\section{Short Communication}

molecular markers; armadillos; habitat fragmentation; molecular ecology

Maximiliano Nardelli

Universidad Nacional de Luján

Luján, ARGENTINA

\section{Corresponding Author Secondary}

Information:

Corresponding Author's Institution:

Universidad Nacional de Luján

Corresponding Author's Secondary Institution:

First Author:

Maximiliano Nardelli

First Author Secondary Information:

Order of Authors:

Maximiliano Nardelli

Ezequiel Alejandro Ibáñez

Dara Dobler

Fabienne Justy

Frédéric Delsuc

Agustín Manuel Abba

Marcelo Hernán Cassini

Juan Ignacio Túnez

Order of Authors Secondary Information:

Funding Information:

\begin{tabular}{ll}
\hline $\begin{array}{l}\text { Centre National de la Recherche } \\
\text { Scientifique }\end{array}$ & Dr. Frédéric Delsuc \\
$\begin{array}{l}\text { Consejo Nacional de Investigaciones } \\
\text { Científicas y Técnicas }\end{array}$ & Dr. Juan Ignacio Túnez \\
\hline $\begin{array}{l}\text { Fondo para la Investigación Científica y } \\
\text { Tecnológica }\end{array}$ & Dr. Juan Ignacio Túnez \\
\hline Universidad Nacional de Luján & Dr. Marcelo Hernán Cassini \\
\hline Universidad Nacional de La Plata & Dr. Agustín Manuel Abba \\
\hline $\begin{array}{l}\text { Institut des Sciences de l'Evolution de } \\
\text { Montpellier }\end{array}$ & Dr. Frédéric Delsuc \\
\hline
\end{tabular}

Abstract:

The screaming hairy armadillo (Chaetophractus vellerosus) is a mammal species containing disjunct and isolated populations. In order to assess the effect of habitat fragmentation and geographic isolation, we developed seven new microsatellite loci isolated from low-coverage genome shotgun sequencing data for this species. Among these loci, six microsatellites were found to be polymorphic with 8 to 26 alleles per locus detected across 69 samples analyzed from a relictual population of the species located in the northeast of the Buenos Aires Province (Argentina). Mean allelic richness and polymorphic information content were 15 and 0.75 , with observed and expected heterozygosities ranging from 0.40 to 0.67 and 0.58 to 0.90 , respectively. All loci showed departures from Hardy-Weinberg equilibrium. The analysis of population 


\begin{tabular}{|l|l|}
\hline & $\begin{array}{l}\text { structure in this relictual population revealed three groups of individuals that are } \\
\text { genetically differentiated. These newly developed microsatellites will constitute a very } \\
\text { useful tool for the estimation of genetic diversity and structure, population dynamics, } \\
\text { social structure, parentage and mating system in this little-studied armadillo species. } \\
\text { Such genetic data will be particularly helpful for the development of conservation } \\
\text { strategies for this isolated population and also for the endangered Bolivian populations } \\
\text { previously recognized as a distinct species (Chaetophractus nationi). }\end{array}$ \\
\hline Suggested Reviewers: & $\begin{array}{l}\text { Andrea Premoli } \\
\text { andrea.premoli@crub.uncoma.edu.ar } \\
\text { Researcher with vast experience in molecular ecology }\end{array}$ \\
\hline Bettina Mahler \\
bemahler@ege.fcen.uba.ar \\
Researcher with vast experience in molecular ecology
\end{tabular}


1 Genetic structuring in a relictual population of screaming hairy armadillo (Chaetophractus vellerosus)

2 in Argentina revealed by a set of novel microsatellite loci

3

4 Maximiliano Nardelli ${ }^{1}$; Ezequiel Alejandro Ibáñez ${ }^{1}$; Dara Dobler ${ }^{1}$; Fabienne Justy²; Frédéric Delsuc ${ }^{2}$; Agustín

5 Manuel $\mathrm{Abba}^{3}$; Marcelo Hernán Cassini ${ }^{1,4}$; Juan Ignacio Túnez ${ }^{1}$.

$6 \quad{ }^{1}$ Departamento de Ciencias Básicas, Universidad Nacional de Luján, Luján, Argentina.

$7 \quad 2$ Institut des Sciences de l'Evolution, UMR 5554, CNRS, IRD, EPHE, Université de Montpellier,

8 Montpellier, France.

$9{ }^{3}$ Centro de Estudios Parasitológicos y de Vectores (CEPAVE), CCT-CONICET, Universidad Nacional de La

10 Plata, La Plata, Argentina.

$11{ }^{4}$ Laboratorio de Biología del Comportamiento, IBYME-CONICET, Buenos Aires, Argentina.

12 Corresponding autor: Maximiliano Nardelli, mnardelli83@yahoo.com.ar 


\section{Abstract}

14 The screaming hairy armadillo (Chaetophractus vellerosus) is a mammal species containing disjunct and

15 isolated populations. In order to assess the effect of habitat fragmentation and geographic isolation, we

16 developed seven new microsatellite loci isolated from low-coverage genome shotgun sequencing data for this species. Among these loci, six microsatellites were found to be polymorphic with 8 to 26 alleles per locus

18 detected across 69 samples analyzed from a relictual population of the species located in the northeast of the

19 Buenos Aires Province (Argentina). Mean allelic richness and polymorphic information content were 15 and

$20 \quad 0.75$, with observed and expected heterozygosities ranging from 0.40 to 0.67 and 0.58 to 0.90 , respectively.

21 All loci showed departures from Hardy-Weinberg equilibrium. The analysis of population structure in this

22 relictual population revealed three groups of individuals that are genetically differentiated. These newly

23 developed microsatellites will constitute a very useful tool for the estimation of genetic diversity and

24 structure, population dynamics, social structure, parentage and mating system in this little-studied armadillo

25 species. Such genetic data will be particularly helpful for the development of conservation strategies for this

26 isolated population and also for the endangered Bolivian populations previously recognized as a distinct

27 species (Chaetophractus nationi).

28

$29 \quad$ Key words

30 Molecular markers, armadillos, habitat fragmentation, molecular ecology 


\section{Introduction}

33 Reduced population size can cause loss of genetic diversity within populations and the emergence of harmful 34 genetic effects associated with this genetic load. Small isolated populations can suffer from the effects of inbreeding and loss of heterozygosity, leading to a decrease in reproductive success and an increase in extinction probability (Frankham et al. 2002). The deleterious effects of isolation and low effective population size are often exacerbated by habitat loss or fragmentation, a situation experienced by many wild mammal populations in the Argentinean Pampas due to human activities related to cattle raising and farming (Viglizzo et al. 2011; Bilenca et al. 2012). Early detection of potentially deleterious genetic load and loss of genetic variability maximizes our ability to implement a management approach aims at limiting or reversing these effects before they become substantial or irreversible (Hedrick 2001).

The screaming hairy armadillo (Chaetophractus vellerosus; Xenarthra, Chlamyphoridae) has been recently shown to include populations inhabiting high altitude grasslands of Bolivia, Chile, Peru, and northern Argentina, all of them previously recognized as a separate species, the Andean hairy armadillo (Chaetophractus nationi; Abba et al. 2015). Its geographical distribution once restricted to arid and semiarid regions with loose, sandy soil of southeastern Bolivia, northeastern Paraguay and central Argentina (Abba and Cassini 2010; Abba et al. 2011), has thus been largely expanded (Figure 1). In Bolivia, the high-altitude isolated populations are threatened by their overexploitation for traditional purposes and habitat degradation due to agricultural activities (Pérez-Zubieta 2011). In Argentina, a disjunct population of screaming hairy armadillo exists in the northeast of the Pampa region, which is separated from the main distribution area by about 500 km (Crespo 1974; Carlini and Vizcaíno 1987; Abba et al. 2011) (Figure 1). This relictual population is associated with the shelly beach ridges on the coast of the Río de la Plata Estuary, covering an area of less than $900 \mathrm{~km}^{2}$ (Abba and Superina 2010). It is currently at high risk of extinction because the environment is being heavily modified by human activities such as farming, cattle raising, and mining activities (Abba et al. 2011). Such disturbances are thought to affect both individual behavior and population dynamics. For example, Pagnutti et al. (2014) analyzed the home range of the screaming hairy armadillo in the same study area that we analyzed here, which is divided in two pastures with different use intensity (see Materials and Methods for details). Their results showed that the home range of the species was reduced by human disturbance and that individuals from the most disturbed pasture presented a more aggregated 
4

distribution. In addition, the authors did not observe or recaptured the same marked individual in both pastures (AM Abba, personal communication), suggesting limited dispersal between the two areas. From these previous results, some degree of genetic differentiation might be expected between the two areas with different use intensity.

The aim of this work is to conduct a preliminary study of genetic variation and structure in a relictual population of the screaming hairy armadillo by developing a set of microsatellite markers that would be useful for studying the conservation genetics of this species in wild populations. Microsatellites constitute useful genetic markers for estimating genetic diversity, population structuring, demography, social structure, parentage, and mating system (Avise 2004; Andrew et al. 2013). Estimating these parameters will be helpful for the development of future conservation strategies of the endangered populations of screaming hairy armadillos in both the northeast of the Pampas region in Argentina and the high altitude habitats of Bolivia.

\section{Materials and Methods}

\section{Microsatellites development}

We used shotgun genomic data generated in a previous study focused on xenarthran mitogenomics (Gibb et al. 2016). As part of this phylogenetic study, single-end Illumina reads were produced from a C. vellerosus individual from the Mendoza province in Argentina (1,212,063 reads) and from an individual representing the high altitude populations of the Oruro department in Bolivia (790,237 reads), previously referred to as $C$. nationi (see Abba et al. 2015). De novo assembly of these reads was performed with ABySS (Simpson et al. 2009). Identical contigs were collapsed using CD-HIT (Fu et al. 2012). By merging the contigs obtained from the two individuals, we obtained a total set of 4,232 unique contigs of more than $150 \mathrm{bp}$. These contigs were searched for di-, tri-, and tetra-nucleotide repeats using MSATCOMMANDER (Faircloth 2008). Primer design from the resulting 11 candidate loci was subsequently optimized using the BatchPrimer3 web server (You et al. 2008).

\section{Study area, sampling and DNA extraction}

During 8 years (2006-2013) armadillos were sampled in a 100 hectares cattle farm located in Magdalena, Buenos Aires, Argentina ( $35^{\circ} 10.45^{\prime} \mathrm{S}, 57^{\circ} 20.66^{\prime} \mathrm{W}$; Figure 1). The field is bounded on the west by the 
Provincial Route \#11, to the east by the Rio de la Plata Estuary and to the north and south by two artificial canals that flow into this Estuary. These bounds represent physical barriers to dispersal for screaming hairy armadillos. This area is in turn divided in two pastures similarly sized (approximately 50 hectares each), but with different use intensity. The northern one, characterized by a low intensity of use, is mainly used for cattle and sheep breeding, while the southern one, with high intensity of use, is covered by modified grassland used for livestock feeding.

Handling technique was used to capture individuals, sometimes helped by a net. Small ear punches of tissues were collected from 69 armadillos, 45 from the northern pasture and 24 from the southern one. Permanent, semi-permanent and temporal marks were made in each individual in order to avoid resampling. Tissue samples were used for DNA extraction using a phenol:chloroform and DNA precipitation method (Sambrook et al. 1989). Precipitated DNA was resuspended in buffer TE, $\mathrm{pH}=8.0$, quantified in a spectrophotometer at $260 / 280 \mathrm{~nm}$ and stored at $-20^{\circ} \mathrm{C}$.

\section{Microsatellite amplification}

Optimal PCR conditions for 11 candidate loci were initially assayed using DNA obtained from 10 individuals. PCR amplifications were successful for seven of the 11 loci tested in all 69 samples. The PCR amplification protocol consisted of one step of denaturation at $95^{\circ} \mathrm{C}$ for $3 \mathrm{~min}$; followed by 35 cycles, each involving denaturation at $95^{\circ} \mathrm{C}$ for $30 \mathrm{sec}, 45 \mathrm{sec}$ at annealing temperature (Table 1) and extension at $72^{\circ} \mathrm{C}$ for $30 \mathrm{sec}$; with a final extension step at $72^{\circ} \mathrm{C}$ for $5 \mathrm{~min}$. PCR amplifications were carried out in $25 \mu \mathrm{l}$ volumes containing 10 ng of DNA, $1 \times$ PCR buffer (PB-L, Argentina), $3 \mathrm{mM} \mathrm{MgCl}_{2}, 0.2 \mathrm{mM}$ of dNTPs mix (Genbiotech, Argentina), $0.4 \mu \mathrm{M}$ of each primer (Genbiotech, Argentina), $0.5 \mathrm{U}$ of Taq DNA polymerase (PB-L, Argentina) and sterile distilled water to reach final volume. One of the primers of each pair was dyed with FAM or HEX fluorochromes (Table 1). Amplification products were visualized by migration on $2 \%$ agarose gel electrophoresis at $4 \mathrm{~V} / \mathrm{cm}$.

\section{Data analyses}

Genotypes were determined using GeneMarker v. 2.2.0 (Softgenetics). Allelic richness, probability of identity, probability of identity among siblings, and observed and expected heterozygosities, were estimated 
with GenAlEx v. 6.5 (Peakall and Smouse 2012). Adjustment to Hardy-Weinberg Equilibrium (HWE) and

117 FIS values for all loci were calculated using GENEPOP v.4.2 (Raymond and Rousset 1995). Polymorphic

118 Information Content (PIC) was evaluated using Microsatellite Toolkit v. 3.3.1 (Park 2001). Null allele

119 frequency was estimated using FreeNA (Chapuis and Estoup 2007). An AMOVA analysis was performed with Arlequin v. 3.5 (Excoffier et al. 2010) in order to evaluate potential genetic differences between the

121 southern and northern pastures. A corrected $\mathrm{F}_{\mathrm{ST}}$ value was obtained with FreeNA in order to determine the effect of null alleles on genetic structure estimation. Finally, population structuring in our data set was tested using STRUCTURE 2.3.4 (Pritchard et al., 2000). This approach uses a Bayesian clustering analysis to assign individuals to clusters $(K)$ without prior knowledge of their population affinities. STRUCTURE simulations were performed with the number of presumed clusters ranging from $K=1$ to $K=7$ and 20 runs per tested $K$ value following the recommendations of Evanno et al. (2005). For each run, the initial burn-in period was set to 100,000 followed by 1,000,000 Markov Chain Monte Carlo (MCMC) iterations. The most probable number of clusters was determined by plotting Delta $K$ as a function of $K$ using Structure Harvester (Earl and vonHoldt 2012), an on-line application of the Evanno's method (Evanno et al. 2005). We chose a proportion of membership threshold value of $\mathrm{q} \geq 0.8$ to assign individuals to clusters. This value provides a statistical cut-off within the range of suggested values in the literature (Manel et al. 2002) and indicates that $\geq 80 \%$ of ancestry can be attributed to the respective subpopulation. Finally, using the Alleles in Space (AIS) software (Miller 2005), we performed a Genetic Landscape Shape interpolation analysis in order to relate genetic data with the geographic coordinates of individuals.

\section{Results and Discussion}

\section{Microsatellites characterization}

138 We developed seven microsatellite loci and used them to analyze 69 individuals from an isolated population 139 of the screaming hairy armadillo (C. vellerosus). The seven loci assayed were successfully amplified.

140 However, one of them (locus 5656_750_3130) was found to be monomorphic in our sample set, amplifying a

141 unique fragment of $124 \mathrm{bp}$. The other six loci were polymorphic with a number of alleles ranging from 8 to 26

142 and a mean allelic richness of 15 (Table 1). All polymorphic loci were highly informative, registering PIC

143 values greater than or equal to 0.530 , with a mean of 0.752 (Table 1). 
145 loci were $1.0 \times 10^{-7}$ and $3.2 \times 10^{-3}$, respectively. This result indicate that any individual in this population

146 could be identified, and distinguished from the other individuals in the population, with a probability greater

147 than 0.99 . Individual identification is crucial for carrying out behavioral studies in wild populations aiming at

148 determining the mating system or the presence of a social structure (Prodöhl et al. 1996). The newly

149 developed microsatellites will allow such surveys in the screaming hairy armadillo for which these life-

150 history traits are poorly characterized.

151 Observed heterozygosities estimated from our microsatellite loci ranged from 0.403 to 0.672 , averaging

152 0.583. Expected heterozygosities varied from 0.584 to 0.898 , with a mean value of 0.766 . None of the six

153 polymorphic loci adjusted to $\operatorname{HWE}(\mathrm{p}<0.001$; Table 1$)$. Five of them showed positive $\mathrm{F}_{\text {IS }}$ values, but only the

154 value for loci 300_304_832 was significant (Table 1). Waples (2015) conducted an exhaustive study

155 analyzing the possible causes of departures from HWE in natural populations. The possible causes include:

156 overlapping generations, population structure, endogamy, small effective population size, and genotyping

157 errors (i.e. null alleles), among others (Waples 2015). Departure from HWE in our data set could be due to an

158 overlapping generations effect, taking into account that samples used in our study were taken from 2006 to

1592013 , and that offspring, juveniles and adults were captured. Another possibility is the presence of null alleles

160 in the data set, which frequencies ranged from 0.029 to 0.261 (Table 1). However, these values should be

161 taken with caution since null alleles frequencies calculated in FreeNA and related software are obtained

162 assuming panmixia and ascribing heterozygote deficiencies to the presence of null alleles. The panmixia

163 assumption is quite hardly supported by our data given the effect of overlapping generations previously

164 mentioned. Population genetic structure (Wahlund effect) would be another possible cause of the HWE

165 deviations observed. In consequence, we carried out an AMOVA and a STRUCTURE analysis (see below) in

166 order to test the existence of population structure. Finally, we cannot reject endogamy or small effective

167 population size as possible causes of the HWE deviation.

168

169

170

Population structure 


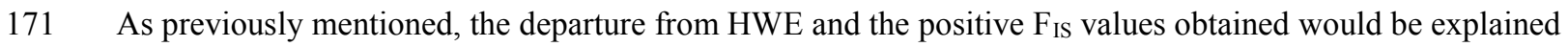
by the existence of a population structuring in our study area. Because a reduced home range due to human disturbance and a more aggregated distribution of individuals in the most disturbed pasture (Pagnutti et al.

174 2014) could have restricted gene flow between pastures, we test the existence of genetic structure between the northern and southern pastures by means of an AMOVA. Our results showed no significant genetic differentiation between pastures $\left(\mathrm{F}_{\mathrm{ST}}=0.007 ; \mathrm{p}=0.095\right)$. The corrected $\mathrm{F}_{\mathrm{ST}}$ value obtained taking into account the presence of null alleles, also support the lack of genetic structuring $\left(\mathrm{F}_{\mathrm{ST}}=0.003 ; \mathrm{p}>0.05\right)$. A STRUCTURE analysis was also carried out without defining subpopulations a priori. Results showed a maximum mean Ln P value at $K=3$ (Mean Ln $\mathrm{P}=-1423.79$ ), suggesting the existence of three genetic groups within our study area (Figure 2A). The Evanno's method confirmed this result, showing a peak at $K=3$. Forty-nine of the 69 individuals (71\%) were assigned to one of the three groups. Two of them were composed of 17 individuals, while the remaining was composed by 15 individuals. Figure $2 \mathrm{~B}$ shows the geographic distribution of the three genetic groups. Most individuals that composed one of these groups were found in the southern pasture, while most individuals that composed the other two groups were found in the northern one. In addition, the Genetic Landscape Shape interpolation analysis (Figure 3) produced a surface plot that qualitatively support results from STRUCTURE. Two major ridges were observed in the landscape, indicating the areas of greatest genetic distance separating the population in three genetically distinct groups. However, field surveys did not detect evidence of physical barriers to dispersal in the study area that might explain this genetic structuring. The observed genetic structure might thus be due to the social behavior or the mating system of the species. Future studies using a higher number of samples and loci together with

191 biological data of the animals obtained during the field works (i.e. sex, age, weight) and parentage analyses, could contribute to a better understanding of this surprising observation.

\section{Comparison with other xenarthrans}

196 The screaming hairy armadillo belongs to Xenarthra, a superorder of Neotropical mammals grouping armadillos, anteaters, and sloths, which are notably understudied (Superina et al. 2014). Few studies have been previously conducted to estimate genetic diversity in xenarthrans using microsatellites as molecular 
markers (Table 2). In this handful of studies, observed heterozygosity values range from 0.06 to 0.71 . The lowest value was registered in an endangered population of the giant anteater (Myrmecophaga tridactyla),

201 which suffered from high inbreeding (Collevatti et al. 2007). The estimated heterozygosity for our population

$202(0.58)$ is comparable with that obtained for populations of the nine-banded armadillo (Dasypus novemcinctus) that are abundant and inter-connected with other populations (Prodöhl et al. 1996; Loughry et al. 2009; Chinchilla et al. 2010; Arteaga et al. 2012). This result is somewhat unexpected considering that our population occupies a relatively restricted area with high level of geographic isolation. Future studies will be necessary to understand the underlying mechanisms involved in such a high level of genetic variability in the screaming hairy armadillo.

\section{Conclusions}

210 Our results show that these microsatellite loci can be useful to study this particularly isolated population and 211 other populations of $C$. vellerosus, such as the endangered populations that live in the Andean region of Bolivia (Abba et al. 2015). These loci might also prove useful for the study of the population genetics of other

213 closely related euphractine armadillo species such as Chaetophractus villosus, Euphractus sexcinctus, and

214 Zaedyus pichiy (Abba et al. 2015). Finally, the genetic structuring described here might have to be considered

215 in future conservation actions, taking into account that this relictual population is highly impacted by human

216 activities and is about $500 \mathrm{Km}$ away from the core distribution area of the species.

\section{Funding}

This work has been financially supported by the Centre National de la Recherche Scientifique, Consejo Nacional de Investigaciones Científicas y Técnicas of Argentina (PIP No. 11420100100189), Agencia Nacional de Promoción Científica y Tecnológica of Argentina (PICT-2010-1978), Universidad Nacional de Luján, Argentina (Fondos Finalidad 3.5), and Universidad Nacional de La Plata. This study has benefited from an "Investissements d'Avenir" grant managed by Agence Nationale de la Recherche (CEBA, ref. ANR10-LABX-25-01). This is contribution ISEM 2016-XXX-SUD of the Institut des Sciences de l'Evolution de Montpellier. 


\section{Acknowledgments}

228 We thank L.G. Pagano and M.C. Ezquiaga for their invaluable assistance during fieldwork. Our thanks also 229 extend to the farm owners (Landa Family) and workers that allowed access to their property. Stéphane

230 Garnier and two anonymous reviewers provided comments that helped improved a previous version of the 231 manuscript.

232

\section{Figure legends}

Figure 1 Geographical range of Chaetophractus vellerosus and location of the relictual population (Magdalena, Buenos Aires Province) where sampling was carried out. Map was extracted from IUCN SSC Anteater, Sloth and Armadillo Specialist Group, Chaetophractus vellerosus, The IUCN Red List of Threatened Species.

Figure 2 Results of the STRUCTURE analysis. A) STRUCTURE bar plot for the screaming hairy armadillo. Each bar represents one individual and each color (light grey, dark grey and black) represents the posterior probability of the individual to belong to that cluster. B) Geographic distribution of the 49 individuals assigned to each of three genetic groups. Colors correspond to those in Figure 2A.

Figure 3 Results of the Genetic Landscape Shape interpolation analysis using a 50 x 50 grid and a distance weighting parameter (a) of $1 . \mathrm{X}$ and $\mathrm{Y}$ axes correspond to geographic locations within the overall physical landscape examined in this study. Surface plot heights reflect genetic distances. Arrows indicate the two major ridges in the landscape (areas with the highest genetic distance).

\section{References}

Abba AM, Cassini MH (2010) Ecological differences between two sympatric species of armadillos (Xenarthra, Mammalia) in a temperate region of Argentina. Acta Theriol 55:35-44.

Abba AM, Cassini GH, Cassini MH, Vizcaíno SF (2011) Historia natural del piche llorón Chaetophractus vellerosus (Mammalia: Xenarthra: Dasypodidae). Rev Chil Hist Nat 84:51-64. 
Abba AM, Cassini GH, Valverde G, Tilak MK, Vizcaíno SF, Superina M, Delsuc F (2015) Systematics of hairy armadillos and the taxonomic status of the Andean hairy armadillo (Chaetophractus nationi). $\mathrm{J}$ Mammal 96:673-689.

Abba AM, Superina M (2010) The 2009/2010 armadillo Red List Assessment. Edentata 11:135-184.

Andrew RL, Bernatchez L, Bonin A, Buerkle CA, Carstens BC, Emerson BC, Garant D, Giraud T, Kane NC, Rogers SC (2013) A road map for molecular ecology. Mol Ecol 22:2605-2626.

Arteaga MC, Piñero D, Eguiarte LE, Gasca J, Medellín RA (2012) Genetic structure and diversity of the ninebanded armadillo in Mexico. J Mammal 93:547-559.

Avise JC (2004) Molecular markers, natural history, and evolution. Sinauer Associates Inc, Sunderland.

Bilenca D, Codesido M, González Fischer C, Pérez Carusi L, Zufiaurre E, Abba AM (2012) Impactos de la transformación agropecuaria sobre la biodiversidad en la provincia de Buenos Aires. Revista del Museo Argentino de Ciencias Naturales, Nueva Serie 14:189-198.

Carlini AA, Vizcaíno SF (1987) A new record of the armadillo Chaetophractus vellerosus in the Buenos Aires Province of Argentine: possible causes for the disjunct distribution. Stud Neotrop Fauna and Environ 22:53-56.

Chapuis MP, Estoup A (2007) Microsatellite null alleles and estimation of population differentation. Mol Biol Evol 24:621-631.

Chinchilla L, Woodard A, Loughry WJ, Brooks CP, Welch ME (2010) Microsatellite markers for the study of leprosy in nine-banded armadillos. In: Molecular ecology resources primer development consortium. Permanent genetic resources added to molecular ecology resources database. Mol Ecol Resour 10:10981105.

Collevatti RG, Leite KC, de Miranda GH, Rodrigues FH (2007) Evidence of high inbreeding in a population of the endangered giant anteater, Myrmecophaga tridactyla (Myrmecophagidae), from Emas National Park, Brazil. Genet Mol Biol 30:112-120.

Crespo JA (1974) Comentarios sobre nuevas localidades para mamíferos de Argentina y Bolivia. Revista del Museo Argentino de Ciencias Naturales “Bernardino Rivadavia”, Zoología. 11:1-31.

Earl DA, vonHoldt M (2012) STRUCTURE HARVESTER: a website and program for visualizing STRUCTURE output and implementing the Evanno method. Conserv Genet Resour 4: 359-361. 
Evanno G, Regnaut S, Goudet J (2005) Detecting the number of clusters of individuals using the software STRUCTURE: a simulation study. Mol Ecol 14: 2611-2620.

Excoffier L, Lischer HEL (2010) Arlequin suite ver 3.5: a new series of programs to perform population genetics analyses under Linux and Windows. Mol Ecol Resour 10:564-567.

Faircloth BC (2008) MSATCOMMANDER: detection of microsatellite repeat arrays and automated, locusspecific primer design. Mol Ecol Resour 8:92-94.

Frankham R, Ballou JD, Briscoe DA (2002) Introduction to conservation genetics. Cambridge University Press, Cambridge.

Fu L, Niu B, Zhu Z, Wu S, Li W (2012) CD-HIT: accelerated for clustering the next-generation sequencing data. Bioinformatics 28:3150-3152.

Garcia JE, Boas LV, Lemos MVF, de Macedo Lemos EG, Contel EPB (2005) Identification of microsatellite DNA markers for the giant anteater Myrmecophaga tridactyla. J Hered 96:600-602.

Gibb GC, Condamine FL, Kuch M, Enk J, Moraes-Barros N, Superina M, Poinar HN, Delsuc F (2016). Shotgun mitogenomics provides a reference phylogenetic framework and timescale for living xenarthrans. Mol Biol Evol. doi:10.1093/molbev/msv250.

Hedrick PW (2001) Conservation genetics: where are we now? Trends Ecol Evol 16:629-636.

Loughry WJ, Truman RW, McDonough CM, Tilak MK, Garnier S, Delsuc F (2009) Is leprosy spreading among nine-banded armadillos in the southeastern United States? J Wild Dis 45:144-152.

Manel S, Berthier P, Luikart G (2002) Detecting wildlife poaching: identifying the origin of individuals with Bayesian assignment tests and multilocus genotypes. Conserv Biol 16:650-659.

Miller MP (2005) Alleles In Space (AIS): computer software for the joint analysis of interindividual spatial and genetic information. J Hered 96:722-724.

Moss WE, Pauli JN, Gutiérrez GA, Young AM, Vaughan C, Herrera G, Peery MZ (2011) Development and characterization of 16 microsatellites for Hoffmann's two-toed sloth, Choloepus hoffmanni. Conserv Genet Res 3:625-627. 
Moss WE, Peery MZ, Gutiérrez-Espeleta GA, Vaughan C, Herrera G, Pauli JN (2012) Isolation and characterization of 18 microsatellite markers for the brown-throated three-toed sloth, Bradypus variegatus. Conserv Genet Res 4:1037-1039.

Pagnutti N, Gallo J, Superina M, Vizcaíno SF, Abba AM (2014) Patrones estacionales de distribución espacial y área de acción del piche llorón, Chaetophractus vellerosus (Cingulata: Dasypodidae), en Magdalena, Buenos Aires, Argentina. Mastozool Neotrop 21:59-65.

Park SDE (2001) Trypanotolerance in West African cattle and the population genetic effects of selection. PhD thesis, University of Dublin.

Peakall R, Smouse PE (2012) GenAlEx 6.5: genetic analysis in Excel. Population genetic software for teaching and research-an update. Bioinformatics 28:2537-2539.

Pérez-Zubieta JC (2011) Intensidad de uso de hábitat del quirquincho andino (Chaetophractus nationi) en zonas aledañas a asentamientos humanos de la provincia de Sur Carangas, Oruro, Bolivia. Edentata $12: 28-35$.

Pritchard JK, Stephens M, Donnelly P (2000) Inference of population structure using multilocus genotype data. Genetics 155:945-959.

Prodöhl PA, Loughry WJ, Mcdonough CM, Nelson WS, Avise JC (1996) Molecular documentation of polyembryony and the micro-spatial dispersion of clonal sibships in the nine-banded armadillo, Dasypus novemcinctus. Proc R Soc Lond B 263:1643-1649.

Raymond M, Rousset F (1995) GENEPOP (version 1.2): population genetics software for exact tests and ecumenicism. J Hered 86:248-249.

Sambrook J, Fritsch EF, Maniatis T (1989) Molecular Cloning: a Laboratory Manual. Cold Spring Harbor Press, New York.

Simpson JT, Wong K, Jackman SD, Schein JE, Jones SJ, Birol I (2009) ABySS: a parallel assembler for short read sequence data. Genome Res 19:1117-1123.

Superina M, Pagnutti N, Abba AM (2014) What do we know about armadillos? An analysis of four centuries of knowledge about a group of South American mammals, with emphasis on their conservation. Mammal Rev 44:69-80. 
335 Viglizzo EF, Frank FC, Carreño LV, Jobbágy EG, Pereyra H, Clatt J, Pincén D, Ricard MF (2011) Ecological 336 and environmental footprint of 50 years of agricultural expansion in Argentina. Glob Change Biol $337 \quad 17: 959-973$.

338 You FM, Huo N, Gu YQ, Luo MC, Ma Y, Hane D, Lazo GR, Dvorak J, Anderson OD (2008) BatchPrimer3: a high throughput web application for PCR and sequencing primer design. BMC Bioinf 9:253.

340 Waples RS (2015) Testing for Hardy-Weinberg proportions: have we lost the plot? J Hered 106:1-19. 341 


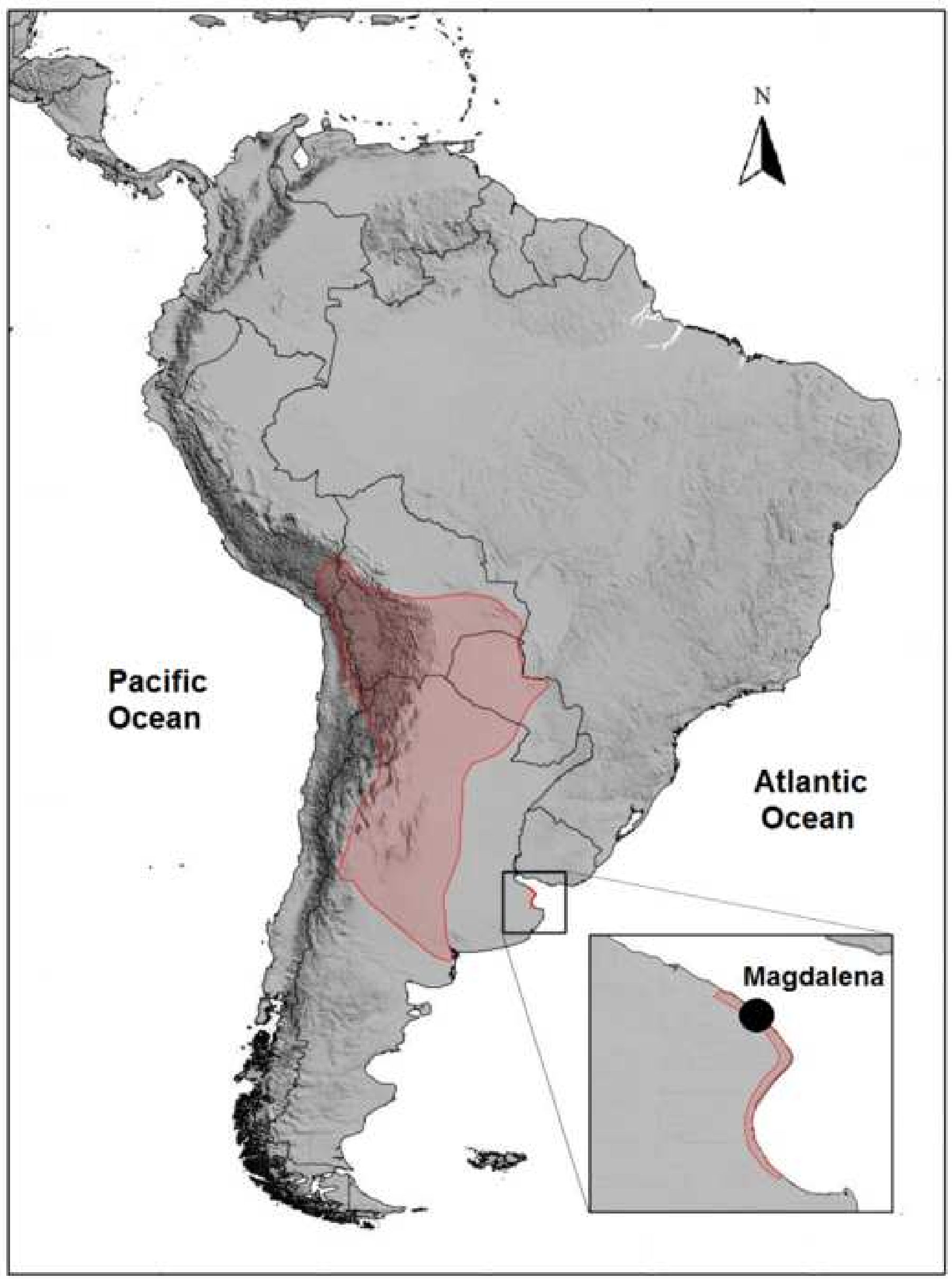




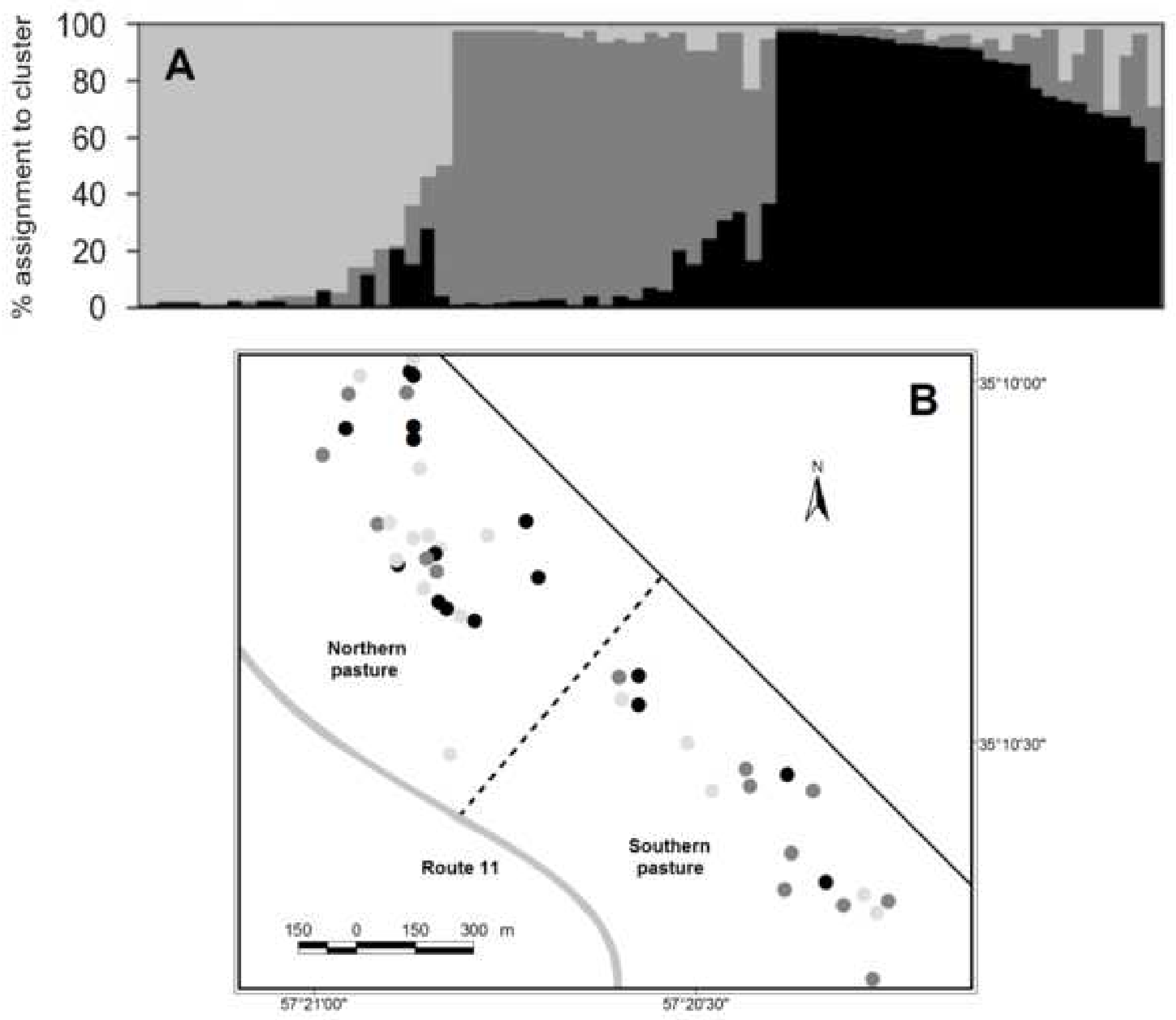




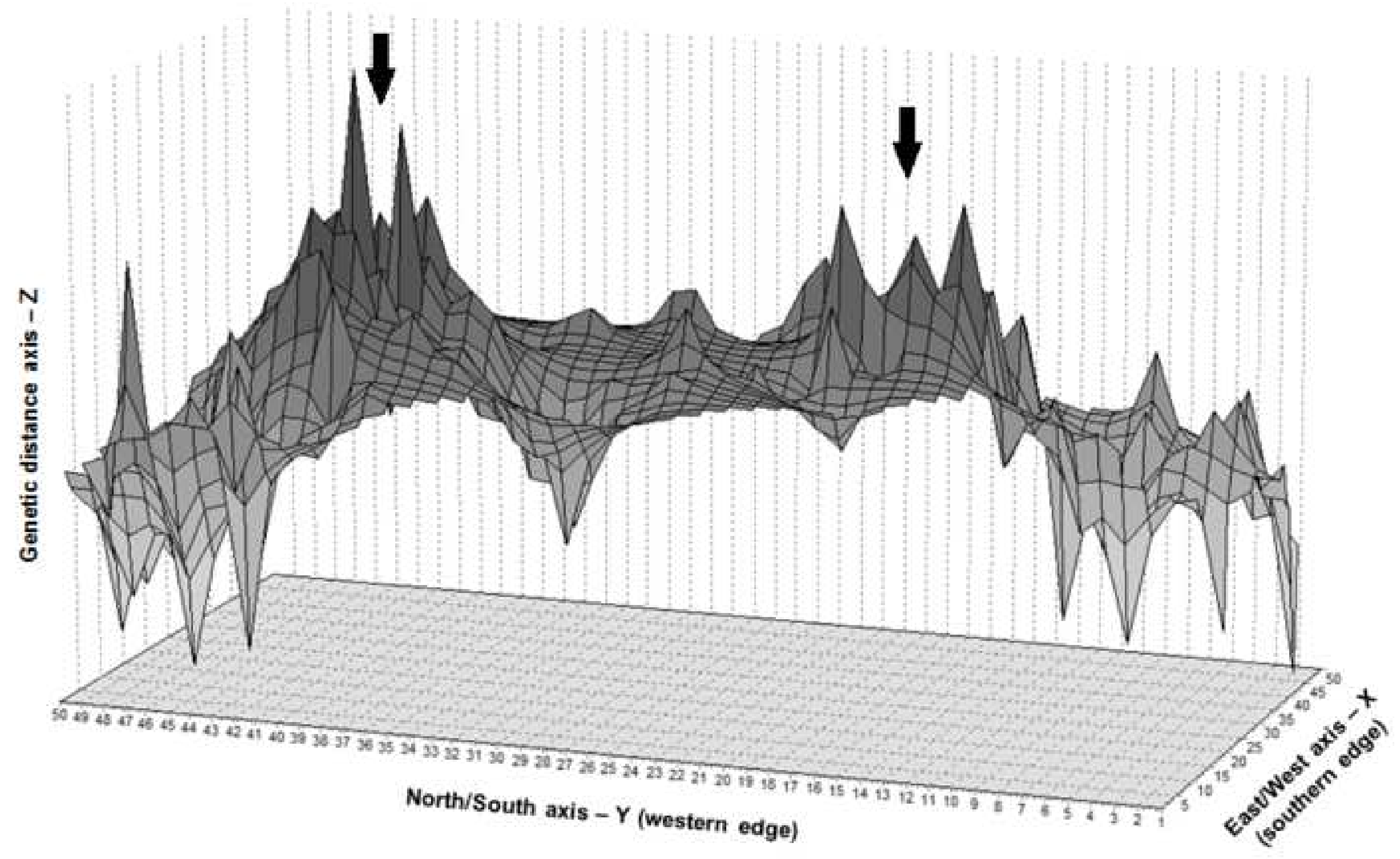


Table 1. General features of microsatellite loci for the screaming hairy armadillo (Chaetophractus vellerosus).

\begin{tabular}{|c|c|c|c|c|c|c|c|c|c|c|c|c|}
\hline Locus name & Primer sequences & $\begin{array}{c}\text { Repeat } \\
\text { motif }\end{array}$ & $\mathrm{T}_{\mathrm{a}}$ & $\mathrm{n}$ & $\begin{array}{l}\text { Size range } \\
\text { (bp) }\end{array}$ & $\mathrm{N}_{\mathrm{A}}$ & PIC & $\mathrm{H}_{\mathrm{o}}$ & $\mathrm{H}_{\mathrm{e}}$ & $P_{\text {HWE }}$ & $\mathrm{F}_{\mathrm{IS}}$ & $\begin{array}{l}\text { Null alleles } \\
\text { freq }\end{array}$ \\
\hline 376_440_1976 & $\begin{array}{l}\text { GACCCGGTTCGATTTAATA } \\
\text { CACTGCTTGACATTCTCATT }\end{array}$ & $(\mathrm{AG})_{13}$ & $56^{\circ} \mathrm{C}$ & 69 & $95-111$ & 10 & 0.708 & 0.551 & 0.738 & $* * *$ & 0.260 & 0.115 \\
\hline 2824_669_1772 & $\begin{array}{l}\text { CTGGGTATTCACACCAGAA } \\
\text { GGGGTGACGAAAGTTAAAG }\end{array}$ & $(\mathrm{AC})_{14}$ & $56^{\circ} \mathrm{C}$ & 68 & $88-108$ & 15 & 0.781 & 0.559 & 0.796 & $* * *$ & 0.304 & 0.148 \\
\hline 54997_179_933 & $\begin{array}{l}\text { CTAACCGTGCATTTTATGG } \\
\text { GGCCTAAGACGGTATTACA }\end{array}$ & $(\mathrm{TC})_{8}$ & $54^{\circ} \mathrm{C}$ & 67 & $71-142$ & 8 & 0.530 & 0.657 & 0.584 & $* * *$ & -0.117 & 0.029 \\
\hline 3972_751_4333 & $\begin{array}{l}\text { TCAAAGACAATGTCCCCTA } \\
\text { ATTTTCCAGCCTTGATCTG }\end{array}$ & $(\mathrm{AC})_{15}$ & $54^{\circ} \mathrm{C}$ & 67 & $77-112$ & 13 & 0.789 & 0.672 & 0.812 & $* * *$ & 0.180 & 0.101 \\
\hline 17379_526_1988 & $\begin{array}{l}\text { CAAGCAAGCAAGCAAG } \\
\text { GCCACGGTTTAGTTAATCA }\end{array}$ & $(\mathrm{AAC})_{8}$ & $49^{\circ} \mathrm{C}$ & 61 & $87-109$ & 18 & 0.741 & 0.656 & 0.771 & $* * *$ & 0.158 & 0.116 \\
\hline 300_304_832 & $\begin{array}{l}\text { ACCCTTCAAAAACACTTATT } \\
\text { TAAAAACAAGCAAGCAAGC }\end{array}$ & $(\mathrm{TTG})_{8}$ & $48^{\circ} \mathrm{C}$ & 67 & $77-168$ & 26 & 0.890 & 0.403 & 0.898 & $* * *$ & 0.556 & 0.261 \\
\hline \multirow[t]{2}{*}{ 5656_750_3130 } & $\begin{array}{l}\text { CGATGAATCAACCCTTAGA } \\
\text { GTGCCTGAAGATGTGTGTC }\end{array}$ & $(\mathrm{GT})_{22}$ & $52^{\circ} \mathrm{C}$ & 69 & 124 & 1 & - & - & - & - & - & - \\
\hline & & & & & Mean & 15 & 0.752 & 0.583 & 0.776 & & & \\
\hline
\end{tabular}

$T_{a}$, annealing temperature. $n$, individuals. $N_{A}$, number of alleles. PIC, polymorphic information content. $H_{o}$, observed heterozygosity. $H_{e}$, expected heterozygosity. $\mathrm{P}_{\mathrm{HWE}}, \mathrm{p}$ value for exact test of Hardy-Weinberg equilibrium. $\mathrm{F}_{\mathrm{IS}}$, inbreeding coefficient.

*** $P<0.0001$ 
Table 2. Studies estimating genetic diversity in xenarthrans using microsatellites.

\begin{tabular}{lllll}
\hline Species & $\mathrm{n}$ & \# loci & Ho & Reference \\
\hline Chaetophractus vellerosus & $\mathbf{6 9}$ & $\mathbf{6}$ & $\mathbf{0 . 5 8}$ & This study \\
Dasypus novemcinctus & 310 & 7 & 0.49 & Prodöhl et al. (1996) \\
Dasypus novemcinctus & 139 & 4 & 0.64 & Loughry et al. (2009) \\
Dasypus novemcinctus & 40 & 9 & 0.46 & Chinchilla et al. (2010) \\
Dasypus novemcinctus & 116 & 5 & 0.62 & Arteaga et al. (2012) \\
Bradypus variegatus & 32 & 18 & 0.71 & Moss et al. (2012) \\
Choloepus hoffmannii & 23 & 16 & 0.55 & Moss et al. (2011) \\
Myrmecophaga tridactyla & 15 & 6 & 0.61 & García et al. (2005) \\
Myrmecophaga tridactyla & 27 & 5 & 0.059 & Collevatti et al. (2007) \\
\hline
\end{tabular}

n, individuals. $H_{0}$, observed heterozygosity. 